\title{
An Empirical Assessment of Dropout Rate of Learners at Selected High Schools in King William's Town, South Africa
}

MANONA, W.W.

\section{Abstract}

T is study investigated and analysed factors responsible for high dropout rate of learners at selected high schools in King William's Town District, Province of the Eastern Cape. The aim of the study is to provide an understanding into inherent problems of early exit of learners in the education sector, which impede the longterm production of professionals with bright future. The main findings of this study revealed that multiple motives, associated with individual characteristics of dropouts and social problems emanating from their family background and influence of the community, prompted learners to dropout. Moreover, learner dropout is inter alia caused by social factors such as lack of resources, the effect of poverty, orphans at school, the distance between the school and the community, drug abuse, pregnancy and HIV and AIDS prevalence in schools, gangsterism and learning barriers. The results of this research suggest that the government should make resources available with regard to scholar transport, school nurses to provide education awareness programmes in relation to early pregnancies, HIV and AIDS infection to improve attendance rate. The Department of Social Development should provide information with regard to benefits available to orphaned learners. The government should ensure sustainable provision of the school nutrition programme to alleviate hunger and poverty. School management should effectively regulate the behaviour of learners to promote discipline in schools so that substance abuse is eliminated.

Keywords: Learners, Dropout, High School, Poverty, Drug Abuse, Alcohol, Teenage Pregnancy, Sexual Abuse, Crime, Gangsterism. 
Assessment of Dropout Rate of Learners at Selected High Schools in King William's Town 165

\section{Introduction}

Several educational philosophers, most notably those considered pedagogues, emphasize that educators should be truly radical, progressive and enlightened. The first conception of education is community education aiming at social justice, thus endeavours to change society through education. Education in this sense is transformative, and moves beyond the simple instilling of knowledge to encouraging students to critically examine their lives and communities. The second conception of education for the community is what is termed 'utilitarian' or 'economic' conceptions of education, where students are taught in order to best contribute to their community, or society, in economic terms (Scholl, 2014:92). In line with the second conception of education for the community, that is, utilitarian or economic conception of education, the argument for this study is that education is for economic development of a nation, and students are presented as human capital. It is argued that a well-educated workforce is critical for a country's economic growth and competitiveness (Scholl, 2014:94), and so schooling ought to be designed with this aim. It is against this background that this study investigated contributory factors impacting on the dropout rate of learners at schools in South Africa, which negates against the government's efforts of creating a profitable and efficient workforce that is geared towards the development of an individual and the social and economic development of South Africa in a globalising world. This paper is anchored on an eclectic approach to make connections between texts and putting forward my own understanding, drawing on other texts to build a context.

According to Griessel and Oberholzer (1994:44), education is a purposive aid that equips children to independently complete their tasks in life. Thus, education is deliberate assistance for children towards their maturity. Education helps learners to accept a particular approved order and orientates them to progress independently in terms of that order. This contributes to the learners becoming more human. The school is an institution which has been established for the purpose of educative teaching and learning. As Duminy and Sohnge (1994:5) point out, the school came into being in the course of the development of civilisation. A fundamental characteristic of the school is its role in the development of the child through the act of knowing. This involves training the child to discriminate (analyse), to understand, to grasp and to learn. The school is concerned with the growth of the child as a whole. The role of the educator is to direct 
the learner towards a goal. Griessel and Oberholzer (1994:45) state that the successful educative activity is terminated when the learner realises that his or her intention runs contrary to the goal of education, and yet he or she is willing to obey the demands of propriety. Griessel, Louw, and Swart (1991:51) contend that the school has an extremely difficult task. Their argument is that the educative task of the school should be so wide that the child, as a future adult, should be able to hold on his or her own in any situation. To qualify as education, teaching has to assist the child to integrate his or her knowledge into a system of values. This is to be done in order for the child to accept his or her task as a participant in the creation of a harmonious world for fellow humanity.

Educative teaching is planned and organised according to the school timetable, work assignment, classroom practice (the preparation of lessons) and other activities. Gunter (1988:11) argues that education is not only concerned with the development of the head and hand of the child, but also with the will and emotions. Therefore, education deals with the child as an indivisible spiritual-physical unit in his or her total existential situation. Education is aimed at more than just knowledge, skills and independent thought, but is principally concerned with the positive formation of the moral character and the development of the entire personality of the maturing adult. As pointed out by Jakuja (2009:13-14), although learner dropout affects all grade levels in South Africa, the high dropout rate of learners mostly occurs at high schools and learners usually dropout in the Further Education and Training (FET) band and not in the General Education and Training (GET) band and Higher Education (HE). While there are ongoing debates regarding the grade level mostly affected, dropping out seems particularly prevalent at the primary and secondary school levels. At primary school level, the most affected grade is Grade 1 and at secondary school level, mainly grades 9, 10 and 11 (Motala, Dietiens, Carrim, Kgobe \& Rembe 2007:55).

As the DoE (2001:83) points out, these dropout patterns are primarily manifest in rural communities. Learner dropout analysis by province shows that in the King Williams Town area and the wider rural districts of the Eastern Cape, grades 9, 10 and 11 consistently experience the highest dropout rates. This trend also applies nationally, even after the dropout rate is adjusted for grade repetition (Motala et al., 2007:10). In the Province of the Eastern Cape, the average dropout rate for all grades was 10\% between 2003 and 2006 (DoE, 2006:3). There is also a higher dropout rate amongst male learners than female learners (Motala et al., 2007:11). Mgwangqa and Lawrence (2008: 2) have 
established that the main reason for learners dropping out of school in rural areas is poverty. Poverty serves as an overarching cause for other factors, such as; illnesses, child pregnancies, and hunger. These factors result in learners committing petty criminal offences.

Hawksley, Jacoby, Louw, Coetzee, and Findlay (2002: 138) are of the opinion that teachers and parents need to be made aware that motivation in the home environment and school is an important factor in encouraging learners to continue with their studies. When learners are motivated, they manage stress better and are also eager to initiate learning activities. Motivated learners tend to be more willing to take risks, to remain involved in a learning task and are more committed. This means that motivation energises learners to achieve their goals, which can be intrinsically and extrinsically stimulated. Whitbourne (2002:125) argues that when learners are motivated at home, they wholly take part in the learning and teaching environment for a better quality of education, and teachers who exhibit a strong sense of professional commitment usually influence their students towards higher levels of engagement in their learning process, and more significantly, tend to have much higher classroom on-time attendance rates than teachers who do not display the same professional commitment.

Adrian (2001:18) notes that little research has been done in the area of high-stakes testing and its effect on learner retention and dropout rates. As more States are using high-stakes tests as a means to end social promotion and accountability, it is likely that there will be changes in learner retention and dropout rates. Ideally, learners who are successfully retained would benefit from repeating their current grade level. However, Sadowski (2000:6) states that nearly all of the research about retention shows that it has strong negative effects on children. Adrian (2001:18) mentions 63 studies that were conducted to review the effects of retention. Out of those studies, 54 revealed retention as having negative effects, while 9 revealed retention as having positive results. Attempting to eliminate social promotion by making learners repeat a grade is one of the issues behind high-stakes testing and high school exit examinations. According to Heubert and Hauser (1999:122-129), evidence suggests that retention is typically not beneficial in the education process as it leads to lower academic achievement and a higher dropout rate. Research data indicates that simply repeating a grade does not generally improve achievement. Thus, adopting a policy of learner retention would be cause for concern. 


\section{Problem Statement}

Once learners reach high school, they seem to lose focus and become less interested in fulfilling their educational goals. This leads to learner dropout in schools. Yet, parents of learners expect their children to attend school daily and receive the best education so that they can have a bright future. Considering that education prepares the child for life, if the child drops out, he or she will struggle to succeed in life. There are real social reasons that make it difficult for some learners to succeed and lead them dropping out of school. For example, many learners in South Africa are extremely poor and they dropout because their parents cannot provide for their families. Dropout learners from poor backgrounds also tend to be involved in crime. Young people are under a lot of pressure and consequently, they end up using drugs, smoking cigarettes and drinking alcohol instead of going to school. In line with what Carstens, Pretorius, Vercueil and Walls (2008:20) point out, teenage stress also contributes to learner dropout. The transition from childhood to adulthood brings challenges, thus making teenagers vulnerable to physical and emotional stress. Many learners do not get the support they need when they are experiencing stress. Thus, the high stress levels experienced by learners tend to result in high levels of absenteeism. Pregnancy seems to be another contributing factor to the dropout of learners from school. Thus, learner dropout is a significant problem within the South African context. Not only is learner dropout a problem, it is linked to many other issues that negatively affect society.

\section{Research Objectives}

- To provide an understanding of learner dropout and its dynamics

- To examine factors contributing to the dropout rate of learners in high schools.

- To examine the adverse effects of dropout on the future of learners.

- To provide recommendations on the improvement of the dropout rate in public schools in South Africa.

\section{Research Questions}

- In what way do socio-economic factors contribute learners to contemplate dropping out of school?

- Are there signs displayed by a learner who is contemplating dropping out?

- In what way do the consequences of dropping out of school affect learners? 
- How can the dropout rate be improved in public schools?

\section{Conceptualisation of a School Dropout}

According to Brown (2004:11), the term dropout can be defined as a student who exits the education system before completing the programme for which he or she was registered. This definition could embrace students at all levels of the education system whether primary, secondary or tertiary. However, a classification difficulty arises when students leave one institution and move to another; that is, initially dropping out, but likely to re-appear in another institution in another location. The argument by Brown is that, if a student soon continues his or her education elsewhere, he or she cannot be reasonably classified as a dropout. If a student exits the formal education system at a particular level without completing the programme designed for that level, he or she can be classified as a dropout.

Currently, schools face unprecedented challenges to educate increasingly multicultural and multi-lingual learners in addition to addressing the increasing social problems. Some learners are academically successful, committed and participate in class, while others struggle academically and are disenchanted (Abbas, 2009:1). According to Abbas (2009:1), reports of high levels of drug addiction, teen pregnancies, gang activities, violence, physical and sexual abuse, appear daily in the South African local press. These incidents impact negatively on education in general and on what happens in the school in particular.

Mandela (2000:554), states that "Education is the great engine of personal development. It is through education that the daughter of a peasant can become a doctor, that the son of a mineworker can become the head of the mine, that a child of a farm worker can become the President of a great nation. It is what we make out of what we have, not what we are given, that separates one person from another." "The right to basic education is a fundamental human right and it is reflected in the Constitution of the Republic of South Africa of 1996 and in White Paper 6 (DoE, 2001:11) of the Education Department. 


\section{Social Factors Causing Learner Dropout}

Social factors contributing to learner dropout are:

\section{Poverty}

Poverty in South Africa manifests in ill health, under nourishment, deprivation of privileges, unsupportive environments in informal settlements and squatter camps, language deficiencies, limited social status and a negative view of the future. Other factors which contribute to poverty in South Africa are the backlog in technology, conflict and violence, crime and substance abuse (Prinsloo, 2005:451). Poverty has been identified as a major risk factor for learners to drop out of school. That is why the Department of Education has started a nutrition programme (feeding scheme) at schools, which seeks to alleviate hunger among learners coming from poverty-stricken communities.

\section{Teenage pregnancy}

According to Bezuidenhout (2006:43), teenage pregnancy is viewed as a social problem in many developed and developing countries. It is no longer perceived as a personal problem as it is prevalent in South Africa and society seeks to lower the high incidence of teen pregnancy. Cunningham and Boult (1996:692) point out that the social consequences of teenage pregnancy are dropping out of school, interrupted schooling, falling prey to criminal activity, abortion, ostracism, child neglect, school adjustment difficulties for their children, adoption, lack of social security, poverty, repeated pregnancy and negative effects on domestic life. In South Africa teenage pregnancy is rising each year.

Statistics in the United States reveal that one in three pregnant teenage mothers drop out of school due to pregnancy (Novick, 2001:226). The United States has the highest birth rates recorded amongst teenagers with $48 \%$ of teenagers giving birth between the ages of fifteen and nineteen years of age (Jean-Jacques and Loeber, 2007:300). Only 50\% of teenage mothers (younger than eighteen years old) complete their schooling (Novick, 2001:227). Theron and Dunn (2006:463) state that when teenagers become pregnant, it disrupts their schooling career as they have to leave school in the early stages of their pregnancy. Arguing along similar lines, Phoenix (1991:218) indicates that many 
teenage mothers never return to school and this has a negative impact on their future as they become unemployable after giving birth.

In South Africa, 30\% of teenagers have given birth once by the age of nineteen (Kaufman, De Wet \& Stadler, and 2001:154). They do, however, have the right to return to school after giving birth, as they have the right to quality education as stipulated in the Constitution of the Republic of South Africa of 1996, section 29. This also means that they cannot be expelled or suspended. Many of these teenage mothers return to school as they perceive education as the key factor in gaining access to good employment (Kaufman, De Wet and Stadler, 2001: 55). According to Kaufman, De Wet and Stadler (2001:147-155), this is unlike in many developing countries where teenage mothers cannot return to school after giving birth. This marks the end of education for them. For example, in Mozambique, girls who fall pregnant are automatically expelled from school and in countries such as Togo and Zanzibar. By law, these girls have to drop out of school (Abbas, 2009:14).

Chigona (2007:159) asserts that teenage mothers need support and encouragement to aid their academic performance. Failure to obtain support from their school and home environment results in poor academic performance and may even cause many of them to drop out of school. Abbas (2009:14) states that the consequences of teenage pregnancy include failure at school, dependency on welfare systems, and educational problems affecting the child due to intellectual and emotional inadequacy of the very young mother.

Teenage mothers have a higher risk of poor health and their children, as well as social, cultural and economic regression. The educational effects of teenage pregnancy are that these teenage mothers run a risk of not obtaining the educational skills needed to become self-supporting, economically productive citizens, something which often results in their children entering the educational system with economic and developmental disadvantages (JeanJacques \& Loeber, 2007:299).

\section{Drug Abuse}

A drug is any chemical substance that if taken has a biological and physical effect on a person, and it causes one's body to function differently. It may be 
legal or illegal, natural or man-made and means using a chemical substance a great deal. Drug refers to a substance that acts on the nervous system such as stimulants or narcotics that may cause addiction (Gills, 1992:107). This has a negative effect on the person's physical, mental or emotional well-being. An addict is a person whose life is controlled by drugs. Drug use and abuse is a worldwide problem. It is a well-known fact that younger people are using drugs such as glue, thinners, cooking sprays, petrol and so on (Euvrard, Findlay \& Nduna, 2006:75)

Many of the social problems such as drug addiction are also linked to gangsterism in the community (Reckson and Becker, 2005:114). Drug use and abuse by learners is not a new phenomenon as it has prevailed for more than decades, worldwide and especially in South Africa. Drug use and abuse by high school learners has brought about many problems in schools and society at large (Hewana, 1999:164). The World Health Organisation maintains that drug use and abuse has all over the world been identified as a problem through all ages. Alcohol is the most commonly used drug by adolescents of the world, and is followed by cigarettes. Adolescents at a very young age (12 to 13 years) were reported to be using drugs such as alcohol, cigarettes and marijuana (World Health Organisation, 1999:102).

Drug use and abuse by learners at schools is a worldwide phenomenon and has negative consequences on school performance and learning, as well as the general well-being of those who abused them. In South Africa, the consumption of alcohol and dagga smoking amongst adolescents are very high (Edmonds \& Wilcocks, 1995:144). As Edmonds \& Wilcocks (1995:144) argue, these have negative consequences that include poor school performance, high number of dropouts and social misfits. These are publicised on television and radio education programmes, as well as academic publications. Yet learners continue to use and abuse drugs. Amongst the consequences of drug abuse is that these adolescents are more likely to end up dropping out of school, while some may end up being patients suffering from psychological problems that will last a lifetime (Edmonds \& Wilcocks, 1995:145). 


\section{HIV and AIDS infection or affection}

According to Coetzee, Hawksley and Louw (2002:92), the Human Immunodeficiency Virus (HIV) affects different people in different ways. Coetzee, Hawksley and Louw (2002:95) state that most young people living with HIV and Acquired Immune Deficiency Syndrome (AIDS) in South Africa contracted the virus through sexual intercourse. It is estimated that there are 1.9 million AIDS orphans where one or both parents are deceased in South Africa (Coetzee, Hawksley and Louw 2002:96). Another estimate puts the proportion of maternal orphans (those who have lost their mother, orphaned by AIDS) as over 70 percent (Coetzee, Hawksley and Louw, 2002:97)

As Broadus and Bryan (2008:166) point out, orphans may put pressure on older relatives who become their primary carers. They may have to relocate from their familiar neighbourhood; and siblings may be split apart, all of which can harm their development. National surveys of sexual behaviours of the youth showed that the 15-24 age groups is vulnerable group in terms of HIV and AIDS risk (Shisana and Simbayi, 2004:22). An individual's ideas about themselves and their health could be instrumental in effecting behaviour change. The objective of the health intervention or training programme could be that of identifying individuals' conceptions about themselves and how they protect themselves from diseases such as HIV and AIDS. Intervention programmes could identify risk factors and incorporate them into HIV and AIDS risk reduction programmes (Shisana and Simbayi, 2004: 123).

\section{Gangsterism and Bullism}

Sociologists tend to concentrate on deviant behaviour as the cause of crime. When prescribed goals are sought by all members of society, certain means to achieve those goals become institutionalised as right and proper. However, when certain groups are constantly denied access to those means, these groups may reject the goals or turn to deviant behaviour to achieve those goals, by causing crime as well as joining gangs (Montero and McDowell, 1986:381). MacMaster (2007:278) indicates that gangsterism has been a part of the communities of the Cape Flats since the establishment of townships under apartheid laws. Pinnock and Schärf (1984:99) contend that the main reason for 
the formation of gangs is the fact that there was stark poverty in an equally impoverished environment. However, even today gangsterism in South Africa, particularly in the Western Cape, remains an insidious problem.

South Africa remains one of the most violent countries in the world. It is estimated that between 40 to $60 \%$ of crime is related to gang activity in the Western Cape (Nott, Shapiro and Theron, 1990:1; Kinnes, 1995:3). Kagee and Frank (2005:5) point out that gang activity has been identified as one of the main causes of serious violent crimes in the Western Cape. This is also confirmed by Standing (2006:256) who reports that gangs cause up to $70 \%$ of all crime on the Cape Flats. The Department of Community Safety (2005:12) reveals that gang members are becoming younger and start from around ages twelve and thirteen. This correlates with the findings from the South African Human Rights Commission (2006), which indicates that gang activity has filtered into schools with the result that there is now an increase of gang membership among learners and gang-related incidents on school grounds.

Many of the social problems such as drug addiction are also linked to gangsterism in the community (Reckson and Becker, 2005:114). The Western Cape has been estimated to have about 100, 000 gang members (Reckson and Becker, 2005:107) and every year there are more murders in Cape Town alone than in the whole of Britain (Nott, Shapiro and Theron, 1990:1). Gang members are responsible for most of the crime such as house breaking, car break-ins and thefts. They terrorise communities with drive-by shootings, rape (which could lead to teenage pregnancy) and intimidation. In an interview conducted by Nott, Shapiro and Theron's study on gangsterism, one grade six learner recounts; "They (gang members) sell drugs in front of children and tell innocent teenagers to sell it for them. They influence teenagers to try it and then children feel high and then they tell them to break into houses, then they steal video machines, jewellery and other things" (Nott, Shapiro and Theron, 1990:5).

According to Reckson and Becker (2005:109), gangsterism results from wider social, political and historical contexts. This problem is exacerbated by factors such as unemployment, poverty, lack of community concern, poor school policies and inadequate social services (Reckson and Becker, 2005:109). These factors can cause learners to drop out of school, which can further lead them to 
a life of crime. MacMaster (2007:278) believes that gangsterism is rooted in multiple socio-economic and political causes and it affects the lives of individuals, families and whole communities. However, Bezuidenhout (2006:74) argue that gangsterism is closely linked to both the social disorganisation perspective and the deviant behaviour perspective as teenagers join gangs because of poor parenting, peer pressure and poverty. As such, these teenagers may engage in other risky behaviours such as taking and selling drugs, which are characteristics of the gang culture (Bezuidenhout, 2006:74).

\section{Transition from primary to high school}

The transition from primary school to high School can be a difficult adaptation for learners to make, and it is a critical stage for learners to break through. It offers critical, yet neglected opportunities for intervention and for the formation of significant social attachments, including peer and family relationships (Lan and Lanthier, 2003:121). Peer and family relationships play a big role in reducing the likelihood of dropping out (Marcus and Sanders-Reio, 2001:134).

\section{Lack of motivation}

Motivation of learners can be characterised by their willingness to initiate learning activities, their continued involvement in a learning task, and their long-term commitment to learning. Learners need to be motivated both in the home and school environment. Teachers and parents should be aware that motivation in the home environment and school is an important factor to encourage learners to continue with their studies. When learners are motivated, they manage stress and are also eager to initiate learning activities, they are willing to take risks, they remain involved in a learning task and they show a commitment (Coetzee, Louw and Hawksley, 2002:139).

This statement emphasises that motivation encourages learners to achieve their goals which can be intrinsically and extrinsically stimulated. When learners are motivated at home they take part in learning and teaching environment in totality for a better quality of education. Teachers who exhibit a strong sense of professional commitment usually influence their learners towards higher levels of engagement in their learning process and, more significantly, tend to have 
much higher classroom on-time attendance rates than teachers who do not display the stated (Whitbourne, 2002:125).

\section{Suspension and expulsion}

According to the South African Schools Act (SASA), 1996 (Act 84 of 1996), (9) (1), the governing body of a public school may, after a fair hearing, suspend a learner from attending school as a correctional measure for a period not longer than a week. Section (2) of Act 84 of 1996 (SASA) states that subject to any applicable provincial law, a learner at a public school may be expelled only by the Head of Department if found guilty of serious misconduct after a fair hearing. According to Terhoeven (2009:17), learners are usually expelled from school as a punishment for bad behaviour. Expulsion can be viewed as an asset to the teacher, but it does not help the learner. In South Africa, only the governing body has the right to suspend a learner from attending school.

\section{Academic Performance-Related Factors that Put Learners at Risk of Dropping Out}

According to Terhoeven (2009:14), factors that put learners at risk of dropping out include retention, academic performance and engagement, transition from primary school to high school, lack of motivation, suspension and expulsion, and poverty. For clarification purposes a brief explanation of these factors is essential.

\section{Retention}

Retention refers to the practice of having a learner repeat a grade level because of low academic performance (Roderick, 1995:133). Retention is one of the most common factors that put learners at risk of dropping out because the learner might become an overage learner in that particular grade. The grade retention in South Africa is higher in the FET phase than in the GET phase (DoE, 2001:35). Grade retention is one of the most powerful predictors of dropping out. Learners who are retained are 2-11 times more likely to drop out during high school than non-retained. 


\section{Academic performance and engagement}

Terhoeven (2009:15) states that academic performance and school engagement are some of the indicators that might lead to school dropout. Academic performance of those learners who struggle in a classroom and fall behind academically, and to school engagement, turn to be disengaged from the school and develop disciplinary problems, such as high rates of absenteeism and truancy, show poor classroom behaviour, learners who participate less in extramural activities and have bad relationships with teachers and peers.

\section{Learning barriers}

Barriers to learning and development are defined as those factors which lead to the inability of the system to accommodate diversity, which lead to learning breakdown or prevent learners accessing educational provision (DoE, 2001:66). Barriers arising from impairments include physical, cognitive, sensory, developmental and learning impairments lead to dropout of learners (Terhoeven, 2009:35). Learners experience the most severe forms of learning difficulties, leading them to dropout at school. The most important way of addressing barriers arising from the curriculum is to make sure that the process of learning and teaching is flexible enough to accommodate different learning needs and styles. The curriculum must therefore be made more flexible across all bands of education so that it is accessible to all learners, irrespective of their learning needs.

\section{THEORIES OF LEARNERS DROPOUT}

Brown (2004:11) states that many students drop out of the secondary level of the school system before completion of the final year, which is a problem faced in many countries, whether developed, developing or under-developed. The greater focus on secondary level dropouts is no doubt due to the accepted tenet of educational philosophy, which states that it is important to extend education for as long as possible within the developmental period from age 14 to age 18 . The more time adolescents have to gain educational experience during the teenage years, the better prepared they will be to face life's challenges (Battin-Pearson, 2000:13). 
Battin-Pearson (2000:214) maintains that identifying the predictors of high school dropouts is a crucial task for researchers because understanding the causes and processes of dropping out can help guide the creation of effective approaches to preventing the problem. It is therefore critical to investigate the phenomenon "early

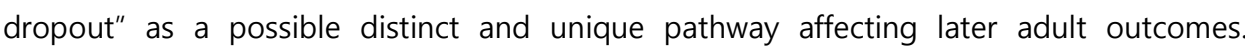
According to Brown (2004: 11), five different theories have been developed to explain the process of dropping out of school. Though each attempts to offer a unique set of affective influences or processes, the interrelationship of certain key variables becomes apparent overall.

\section{Academic Mediation Theory}

Poor academic achievement, typically assessed with standardised achievement tests or grade point average (GPA), has consistently been one of the strongest predictors of dropping out of school when the poor performance is associated with other variables such as anti-social affiliations, personal deviance, family socialisation, and structural strains (Garnier, Stein \& Jacobs 1997:121). Low academic achievement can also mediate the association between low school bonding and ultimately dropping out of school.

\section{General Deviance Theory}

General deviance or specific aspects of deviant behaviour have direct effects on high school dropout. According to Garnier, Stein \& Jacobs (1997:112), teenage drug use directly predicted dropout. Pregnancy has also been a predictor, although differences in family backgrounds were also found to affect the likelihood of the mother eventually completing secondary school. In addition, early sexual activity has been shown to affect academic failure. Teenagers who are not doing well in school and have lower educational aspirations are more likely to have sex during adolescence than those faring better in school (Garnier, Stein \& Jacobs, 1997:112).

\section{Deviant Affiliation Theory}

Dropouts tend to have more deviant friends who also show potential for dropping out, but the mechanism of the influence of these deviant peers on the decision to leave school has not been widely investigated (Fagan and Pabon, 
1990: 215). It is theorised, however, that deviant affiliations have a direct effect on high school dropout over and above the mediating influence of low academic achievement.

\section{Poor Family Socialisation Theory}

Families provide many of the chief foundations and experiences for later life, including academic achievement and success in school. Early influences include divorce and family stress (Garnier, Stein and Jacobs, 1997:395), parental behavioural control and acceptance and, most importantly, parents' own education levels (Ellickson, Bui, Bell and McGuigan, 1998:43). Therefore, low parent expectations and education would have direct effects on school dropouts over and above the mediating influence of low academic achievement.

\section{Structural Strain Theory}

Studies focusing on demographic factors have indicated that dropouts are more likely to be boys than girls, and are more likely to be from families of low socioeconomic status (Rumberger, 1987:163). The overriding hypothesis is that the structural strain factors of gender, ethnicity and socio-economic status will have a direct effect on school dropout over and above the mediating influence of low academic achievement. Brown (2004:11) has noted, however, that the study of the dropout phenomenon and its causes are difficult because the same (environmental) factors may influence different pupils in different ways, and even affect the same pupil in different ways at different times. Janosz, Le Blanc, Boulerice and Tremblay (2000:136) state that while an empirical typology could be useful as a predictive tool with regard to the impact of social risk factors, differential dropout prevention strategies should be adopted for different personality profiles, for example the quiet, disengaged, low-achiever, and maladjusted. Miller (1998:145) states that boys start their schooling later, attend school more irregularly, repeat more grades, drop out earlier, have lower completion rates and achieve less than girls while in school.

\section{RESEARCH DESIGN AND METHODOLOGY}

This investigation is an exploratory, and a qualitative research approach was employed. The gathering of data was conducted at two selected schools in the King William's Town 
District, which is situated in the Province of the Eastern Cape. Purposeful sampling technique has been used because it produces useful information, given that there is an opportunity to study the relevant participants on a small scale for the purpose of the enquiry. The participants, who would provide the best information to achieve the objectives of the study, were the two principals, one from each of the two schools, six educators (three from each of the two schools), and 80 learners (40 learners from each school) were chosen randomly from grade 10, 11 and 12. The number of learners in these grades was 105 in School A, and 114 in School B.

The author conducted interviews with the principals and the six teachers of the two schools. Learners were interviewed in focus groups of 8 - per group. The author, firstly, introduced himself to the participants and then explained the purpose of the study. Participants were also informed that participation was voluntary and could withdraw anytime from the study should they wished to do so. Principals, educators and learners were used in the research. Learners were minors and as such, their parents consented to their participation. In other words, the researcher had to get consent from their parents to participate in the study. Therefore, each learner was provided with a letter to show their parents or guardians that the research was for study purposes. Permission of parents was requested for learners as participants because they were under the age of 18 years. Participants were provided with sufficient information about the study to allow them to decide for or against participation. The principals and educators were given consent forms as participants in the study. This was done after they had been provided with all the information regarding the research and expressed their willingness to voluntarily participate in the research. The respondents were informed that they had a choice to participate in the research voluntarily or to decline as they were not being forced to participate unwillingly. They were also informed of their right to withdraw from participating in the research should they so desire.

\section{LEARNERS DROPOUT IN SOUTH AFRICA: CHALLENGES AND THE WAY FORWARD}

The main findings and recommendations of the study relate to lack of resources, the distance between the school and the community, substance abuse in schools, pregnancy and HIV and AIDS prevalence in school, orphans at schools, and the effect of poverty. The findings and remedies for dropout rates of learners in schools are as follows: 
Assessment of Dropout Rate of Learners at Selected High Schools in King William's Town 181

\section{Lack of Resources}

The empirical findings of this study have revealed that learners are faced with challenges regarding the new curriculum, which contributes to learner dropout in schools. It was established that learners were repeating grades because they struggled to succeed with the new curriculum due to lack of resources. Learners did not have computers and libraries to assist them to conduct research as required by the new curriculum.

Based on the findings above, it is suggested that each school supported by the government financially should ensure that every learner has access to the minimum set of textbooks and workbooks required by the National Curriculum Statement (NCS). The school should increase access for learners to a wider range of media, including computers in order to enrich their education. The School Management Team (SMT) should ensure that schools utilise funds that are allocated for resources responsibly in a transparent and efficient manner so that all the facilities needed for learners could be made available for use. This, in turn, will ensure improvement in the quality of learning and teaching at schools.

\section{The Distance between the School and the Community}

It emerged from the empirical findings that the distance between the school and the community has a direct effect on learner dropout. Most learners travelled a distance of approximately 10 to 15 kilometres to school, which affect their school attendance when the weather is too hot, too cold or when it is raining. These learners are also victims of sexual abuse while walking to school. It has been brought to light that principals and educators are not sensitive to this problem, even though it had adverse consequences with regard to poor attendance of learners.

It is advisable that the principal of the school should write a letter of motivation to the Department of Education, requesting scholar transport for learners who travel long distances in order to alleviate this situation. If learners are assisted with transport to and from school, the attendance rate might improve, and sexual abuse could be eradicated which in turn could reduce the phenomenon of dropout.

\section{Substance Abuse in Schools}

The study has established that the use of drugs by learners contributes to learner dropout. Furthermore, the study has revealed that educators tend to be in the company 
of learners in substance abuse at school; hence these learners do not get punished by educators.

It is suggested that the Department of Education should ensure that all schools are implementing the rules of SASA 84 of 1996 to make sure that educators and principals are playing a leadership role that is exemplary to learners. This will ensure that educators are able to discipline learners when they misbehave. Learners and parents need to be informed about the contents of the Act so that they are aware of rules and consequences of misbehaviour in school. The Department of Education should make sure that the South African Council for Educators effectively regulates behaviour by all educators to promote discipline in schools.

\section{Pregnancy and HIV and AIDS prevalence in schools}

The findings have revealed that the high prevalence of pregnancy and HIV and AIDS amongst learners contributes significantly to dropout. It has been established that learners become pregnant as early as grade 9. It has also been revealed that grade 10 has the highest pregnancy rate.

It would be of much benefit if the government could provide schools with nurses who could provide education awareness programmes about the dangers of early pregnancy, Sexually Transmitted Infections, and HIV and AIDS. These programmes would focus on preventive measures, contraceptives and be encouraged to abstain from sexual activities. If learners are made aware of the consequences of unsafe sexual indulgence, they will be better equipped to make informed decisions regarding their life styles.

\section{Orphans at Schools}

The findings of this study have established that orphaned learners contribute to the dropout rate of learners. It was also revealed that orphaned learners seek employment, rather than remaining in school in order to provide financial assistance to their families.

It is suggested that principals of schools should inform the Department of Social Development about the predicament in which these learners find themselves, so that the necessary assistance could be provided. The Department of Social Development could also assist schools by providing information about benefits available to learners in need of help. 
Assessment of Dropout Rate of Learners at Selected High Schools in King William's Town 183

\section{The effect of Poverty}

The empirical findings of this study have established that poverty amongst learners contributes to learner dropout. It has emerged that learners are unable to successfully complete their school careers due to lack of basic school needs and hunger. The families of these learners are unable to provide them with basic school needs such as school uniform and stationery. The families of these learners are also unable to provide food to them, resulting in learners spending the whole school day hungry and unable to concentrate.

It is recommended that the School Management Team and SGB should inform the Department of Education about the social status of learners who live in poverty so that the importance of a school nutrition programme can be recognise by the Department of Education. If a school nutrition programme is functional then this will ensure that learners will receive food to eat and will be able to concentrate in school, thus motivating them to stay in school.

\section{CONCLUSION AND IMPLICATIONS}

The article concludes that various factors do indeed contribute to dropout rate of learners. It has been revealed that these are not solely attributed to the school environment, but to learners' living conditions and life styles. Those factors comprise of poverty, drug and alcohol abuse, teenage pregnancy, peer pressure, failing the same grade, living without parents, lack of guidance, motivation and support, financial challenges, sexual abuse, involvement in crime, as well as travelling long distances to school. These factors are complex issues, which should be handled by skilled people.

As learners spend a great deal of their time in the school environment, the educator has become an important role-player to assist learners alleviate social problems. It is essential that learners with social problems must, at an early stage, get professional help. Educators who are, due to circumstances, obliged to help these learners, are not necessarily equipped to give the required assistance. It is evident that learners and educators need to be supported, motivated and capacitated to ensure progress with the implementation of the new curriculum. The school, as an institution established to educate, has a responsibility to support learners who are at risk of dropping out. The phenomenon of young people dropping out of school affects the government individuals, societies and the labour market. The effects of dropping out do not only 
have financial implications, but also social implications. Dropping out of school poses challenges regarding self-sufficiency, self-esteem and the ability to make education choices. The Department of Education has policies in place, which address the phenomenon of learners dropping out of school. These policies should consciously and continuously be monitored to ensure that educators are adequately supported. Teachertraining and continuous in-service training programmes should ensure that educators are exposed to current policies and new skills that can assist them in dealing with learners' social problems in alleviation of this phenomenon.

\section{List of References}

- Abbas, F. 2009. Teacher Preparedness in Dealing with Learners' Social Problems. Cape Town: Cape Peninsula University of Technology.

- Adrian, J. J. 2001. An Investigation of the Impact of High Exit Exams on Graduation and Dropout Rates. America: College University of Wisconsin-Stout.

- Bezuidenhout, F.J. 2006. A Reader on Selected Social Issues. Third Edition Pretoria: Van Schaik.

- Brown, M.M. 2004. Gender Differentials at the Secondary and Tertiary Levels of the Caribbean Education System. Kingston: Jamaica.

- Carstens, M., Pretorius, A., Vercueil, P. and Walls, C. 2008. Spot on Life Orientation Grade 9. South Africa: Heinemann Publishers (Pty) Ltd.

- Chigona, A. 2007. Promoting Girls' Education in South Africa: With Special Reference to Teen Mothers as Learners. Cape Town: Cape Peninsula University of Technology.

- Coetzee, E., Hawksley, H. and Louw, H. 2002. Life Orientation Today Grade 9. Cape Town: Maskew Miller Longman.

- Department of Community Safety. 2005. Justice, Crime Prevention and Security Cluster Priority Stations and Social Crime Prevention initiatives Report, Provincial Government of the Western Cape. Cape Town: Government Printers. 
- Dilley, L., Clithore, F., Visser, P., Bottaro, J., Engelbrecht, B., Falken, J., Lundall, B. and Perez, N. 2008. Oxford Successful Life Orientation. South Africa: Oxford University Press Southern Africa (Pty) Ltd.

- Duminy, P. A. and Sohnge, W. A. 1994. Didactics Theory and Practice. Cape Town: Maskew Miller Longman (Pty) Ltd.

- Edmonds, L. \& Wilcocks, L. 1995. Teen Drug Scene South Africa: A Guide for Parents and Schools. Pinego Wrie, Aspen Oak Associates CC.

- Euvrard, G., Findlay, H. and Nduna, N. 2006. Life Orientation Today Grade 9. Cape Town: Longman (Pty) Ltd

- Griessel, G. A. J., Louw, G. J. J. and Swart, C. A. 1991. Principles of Educative Teaching. Pretoria: Acacia Books.

- Griessel, G. A. and Oberholzer, M. O. 1994. Philosophy of Education. Pretoria: Via Afrika.

- Gunter, C. F.G. 1988. Aspects of Educational Theory. Cape Town: University Publishers \& Booksellers (Pty) Ltd.

- Hawksley, H., Jacoby, J., Louw, H., Coetzee, E. and Findlay, H. 2002. Life Orientation Today: Grade 8. Cape Town: Maskew Miller Longman (Pty) Ltd.

- Hewana, N.N. (1999). Prevalence of Substance Use and Abuse among Black University Students and the Factors Influencing them: Implications for Substance Abuse Prevention. South Africa: University of Fort Hare.

- Jakuja, D.P. 2009. An investigation into Social experience of Dropouts Following their Reenrollment in Secondary Schools in the Stutterheim District: Implications for School Leadership. K.W.T.: Fort Hare University.

- Kagee, H. and Frank, C. 2005. COAV Cities Project. Rapid Assessment for Cape Town. Pretoria: Institute for Security Studies.

- Kinnes, I. 1995. The Struggle for the Hearts, Minds and Streets of the Cape Flats. Cape Town: Idasa.

- Mandela, N.R. 2000. Long Walk to Freedom. Cape Town: Vivlia Publishers and Booksellers (Pty) Ltd.

- Miller, E. (1998). Developing a Model of Intervention to Retain Boys in School. Pretoria: Van Schaik. 
- Nott, L, Shapiro, R. and Theron, R. 1990. Gangs: The Search for Self-Respect. Cape Town: National Institute for Crime Prevention and Rehabilitation of Offenders and Social Justice Resource Project.

- Pinnock, D. and Scharf, W. 1984. The Brotherhoods: Street Gangs and State Control in Cape Town. Cape Town: David Phillip.

- Shisana, O. \& Simbayi, L. (2004). Nelson Mandela/HSRC Study of HIV/AIDS: South African National HIV Prevalence, Behavioural Risks and Mass Media Household Survey. Cape Town: Human Sciences Research Council.

- Standing, A. 2006. Organised Crime. A study from the Cape Flats. Pretoria: Open Society Foundation. Institute for Security Studies.

- Terhoeven, L., 2009. The Role of the Teacher Support Team in Preventing Early School Dropout in a High School. Cape Town: University of Stellenbosch.

- World Health Organization (WHO). (1999). Global Status Report on Alcohol. Geneva: WHO.

- Department of Education. (2001). National Plan for Higher Education. Pretoria: Government Printers.

- Republic of South Africa. South African Schools Act. Government Gazette Notice No. 84 of 1996. Pretoria: Government Printer.

- Republic of South Africa. Further Education and Training Colleges Act 16 of 2006. Government Gazette 497 (29469).

- Heubert, J, and Hauser, M. 1999. High Stakes: Testing for Tracking, Promotion and Graduation. [Online].Available: http://www.books.nap.edu/html/highstakes/index_pdf.html [Accessed 29 June 2014].

- Novick, D. 2001. The Teenage Baby Room. Adolescence: Change and Continuing. http://inside.bard.edu/academic/specialproj/darling/adpar.htm [26 March 2014].

- Sadowski, M. 2000. Are High-Stakes Tests Worth the Wager? Harvard Education Letter. [Online]. Available: http://www.edletter.org/past/issues/2000-so/tests.shtml [Accessed 14 October 2014].

- Whitbourne, J. 2002. The Dropout Dilemma: One in Four College Freshman Dropout: What is Going on Here? What Does it Take to Stay In? (Special Report) [O] Available: htt://www.findarticles.com. [Accessed on 10 December 2014]. 
- $\quad$ Battin-Pearson, S. (2000). Predictors of Early High School Dropout: A Test of Five Theories. J. of Educ. Psychology 2000, vol. 92, no. 3, pp. 568-582.

- Broaddus, M. R., \& Bryan, A. (2008). Consistent Condom Use Among Juvenile Detainees: The Role of Individual Differences, Social Bonding, and Health Beliefs. AIDS and Behaviour, $12,59-67$.

- Cunningham, P.W. and Boult, B.E. (1996): Black Teenage Pregnancy in South Africa: Some Considerations. Adolescence, 31(123) pp 691-700 Fall 1996.

- Ellickson, P.L., Bui, K., Bell, R.M., \& McGuigan, K. (1998). Does Early Drug Use Increase the Risk of Dropping Out of High School? Journal of Drug Issues, April 28: 357-380.

- Fagan, J. and Pabon, E. (1990). Contributions of Delinquency and Substance Use to School Dropout Among Inner-City Youth. Youth \& Society, 21, pp. 306-354.

- Garnier, H.E., Stein, J.A. \& Jacobs, J.K. (1997). The Process of Dropping Out of High School: A 19-Year Perspective. American Educational Research Journal, 34, pp. 395-419.

- Janosz, M. \& LeBlanc, M., Boulerice, B., \& Tremblay, R.E. (2000). Predicting Different Types of School Dropouts: A Typological Approach with Two Longitudinal Samples. Journal. of Educational Psychology, 92(1):171-190.

- Jean-Jacques, A. and Loeber, O. 2007. Pregnancy During Adolescence: A Major Social Problem. European Journal of Contraception \& Reproductive Health Care, 12(4), 299-302, December.

- Kaufman, C.E, De Wet, T. and Stadler, J. 2001. Adolescent Pregnancy and Parenthood in South Africa. Studies in Family Planning. 32 (2), 147 - 159. June.

- Kinnes, I. 1995. The Struggle for the Hearts, Minds And Streets of the Cape Flats. Cape Town: Idasa

- Lan, W. and Lanthier, R. 2003. Changes in Students' Academic Performance and Perceptions of School and Self Before Dropping Out of School. Journal for Students Placed at Risk, 8(3):32-309.

- MacMaster, L.L.M. 2007. Social and Economic Emasculation as Contributing Factors to Gangsterism on the Cape Flats. Scriptura, 95: 278-289.

- Marcus, R.F. and Sanders-Reio, J. 2001. The Influence of Attachment on School Completion. School Psychology Quarterly, 16(4):427-444. 
- Mgwangqa, V. \& Lawrence, L. 2008. Why Do Learners Drop Out Of School? Learner Perceptions In The Fort Beaufort District, Eastern Cape, South Africa. Commonwealth Youth Development 6(2): 16-32.

- Motala, S., Dieltiens, V., Carrim, N., Kgobe, P., Moyo, G., and Rembe, S. 2007. Educational Access in South Africa: Country Analytic Report. Johannesburg: Wits EPU.

- Prinsloo, M. 2005. New Literacies as Placed Resources. Perspectives in Education, 23(4):8798.

- Reckson, B. and Becker, B. 2005. Exploration of the Narrative Accounts of South African Teachers Working in a Gang-Violent Community in the Western Cape. International Journal of Social Welfare. 14, $107-115$.

- Roderick, M. 1995. Grade Retention and School Dropout: Debate and Research Questions. Phi Delta Kappa Bulletin, 15:1-6

- Rumberger, R.W. 1987). High School Dropouts: A Review of Issues and Evidence. Review of Educational Research, 57: 101-121.

- Scholl, R. 2014. "Inside-out Pedagogy): Theorising Pedagogical Transformation through Teaching Philosophy. Australian Journal of Teacher Education, 39(6): 89-106.

- Theron, L. and Dunn, N. 2006. Coping Strategies for Adolescent Birth-Mothers Who Return to School Following Adoption. South African Journal of Education. 26(4), 491-499.

\section{AUTHOR'S CONTACT:}

MAMONA, W.W.

Senior Lecturer, Public \& Development Management Saldanha Military Academy Stellenbosch University Email: manonaw@ma2.sun.ac.za 